\title{
Serum Protein Profile Alterations in Hemodialysis Patients
}

$R G$ Langlois, J E Trebes, E A Dalmasso, $Y$ Ying, $R W$ Davies, $M P$ Curzi, B W Colston, KW Turteltaub, J Perkins, B A Chromy, M W Choi, G A Murphy, J P Fitch, S L McCutchenMaloney

\section{Submitted}

Americal Journal of Nephrology 
This document was prepared as an account of work sponsored by an agency of the United States Government. Neither the United States Government nor the University of California nor any of their employees, makes any warranty, express or implied, or assumes any legal liability or responsibility for the accuracy, completeness, or usefulness of any information, apparatus, product, or process disclosed, or represents that its use would not infringe privately owned rights. Reference herein to any specific commercial product, process, or service by trade name, trademark, manufacturer, or otherwise, does not necessarily constitute or imply its endorsement, recommendation, or favoring by the United States Government or the University of California. The views and opinions of authors expressed herein do not necessarily state or reflect those of the United States Government or the University of California, and shall not be used for advertising or product endorsement purposes. 


\title{
Serum Protein Profile Alterations in Hemodialysis Patients
}

Richard G. Langlois $^{\mathrm{a}}$ James E. Trebes $^{\mathrm{a}}$ Enrique A. Dalmasso $^{\mathrm{b}}$ Yong Ying $^{\mathrm{b}}$ Robert W. Davies $^{\mathrm{c}}$ Mario P. Curzi ${ }^{\mathrm{c}}$ Bill W. Colston Jr. ${ }^{\mathrm{a}}$ Kenneth W. Turteltaub ${ }^{\mathrm{a}}$ Julie Perkins ${ }^{\mathrm{a}}$ Brett A. Chromy ${ }^{\mathrm{a}}$ Megan W. Choi ${ }^{\mathrm{a}}$ Gloria A. Murphy ${ }^{\mathrm{a}}$ J. Patrick Fitch ${ }^{\mathrm{a}}$ and Sandra L. McCutchen-Maloney*a

${ }^{a}$ Lawrence Livermore National Laboratory, 7000 East Ave., L-452, Livermore, CA

94550, ${ }^{\mathrm{b}}$ Ciphergen Biosystems, Inc., 6611 Dumbarton Circle, Fremont, CA 94555, ${ }^{c}$ Diablo Nephrology Medical Group, Inc., Walnut Creek, CA 94596

*To whom correspondence should be addressed: smaloney@llnl.gov

To be submitted to: American Journal of Nephrology

Key Words

Hemodialysis $\bullet$ SELDI-TOF-MS • Protein profiling • Proteomics $\bullet$ Biomarkers

\begin{abstract}
Background: Serum protein profiling patterns can reflect the pathological state of a patient and therefore may be useful for clinical diagnostics. Here, we present results from a pilot study of proteomic expression patterns in hemodialysis patients designed to evaluate the range of serum proteomic alterations in this population. Methods: SurfaceEnhanced Laser Desorption/Ionization Time-of-Flight Mass Spectrometry (SELDI-TOFMS) was used to analyze serum obtained from patients on periodic hemodialysis
\end{abstract}


treatment and healthy controls. Serum samples from patients and controls were first fractionated into six eluants on a strong anion exchange column, followed by application to four array chemistries representing cation exchange, anion exchange, metal affinity and hydrophobic surfaces. A total of 144 SELDI-TOF-MS spectra were obtained from each serum sample. Results: The overall profiles of the patient and control samples were consistent and reproducible. However, 30 well-defined protein differences were observed; 15 proteins were elevated and 15 were decreased in patients compared to controls. Serum from one patient exhibited novel protein peaks suggesting possible additional changes due to a secondary disease process. Conclusion: SELDI-TOF-MS demonstrated dramatic serum protein profile differences between patients and controls. Similarity in protein profiles among dialysis patients suggests that patient physiological responses to end-stage renal disease and/or dialysis therapy have a major effect on serum protein profiles.

Full address: Sandra L. McCutchen-Maloney, Lawrence Livermore National Laboratory, 7000 East Ave., L-452, Livermore, CA 94550. Tel: 9254235065 Fax: 4222282 Email: smaloney@1lnl.gov 


\section{Introduction}

Proteomics [1] can be defined as the characterization of total protein composition of an organism. Comparative proteomic analysis under different physiological states may be a powerful approach for identifying biomarkers of health status. Many proteins that are secreted into bodily fluids are differentially expressed in response to physiological changes such as infection or inflammation. Identification of proteins characteristic of a specific disease may provide biomarkers that can be used in simple, non-invasive clinical diagnostics [2-4].

One approach to identify differentially expressed proteins is Surface-Enhanced Laser Desorption/Ionization Time-of-Flight Mass Spectrometry (SELDI-TOF-MS). SELDITOF-MS is an array-based MS technology introduced by Hutchens and Yip [5] that utilizes selective adsorption of a subset of proteins in a given sample to array surfaces differing in chemical coating [6]. Arrays are functionalized for ion exchange, immobilized metal affinity, or hydrophobic selectivity to allow the sample to be fractionated into subsets of proteins with similar chemical affinity. Proteins captured on the array are ionized, and their masses are determined by Time-of-Flight (TOF) MS. A principle advantage of SELDI-TOF-MS is the ability to rapidly screen hundreds to thousands of proteins for differences between diseased individuals and control subjects, even if the protein functions and identities are unknown. Thus, this technique provides a broad unbiased screen for the presence or absence of protein expression differences. Once a candidate protein is detected, however, additional experimental work is required to determine the identity and function of the candidate biomarker. 
To date, the SELDI-TOF-MS technique has primarily been used to screen for candidate biomarkers for specific diseases. This approach has yielded potential biomarkers for prostate, bladder, lung, breast and ovarian cancers as well as Alzheimer's disease [7-12]. In addition, we believe that this approach has considerable potential for monitoring patients with complex chronic conditions or syndromes to identify episodes of relapse, infection, or drug failure. There is one report, for example, of the analysis of urine protein profiles to characterize renal allograft rejection [13]. Analysis of patients with chronic conditions, however, is complicated by protein profile alterations due to the underlying condition and potential patient-to-patient variability in disease state. The ability to rapidly screen large numbers of protein types per patient provides a detailed protein profile facilitating interpretation of these complex factors $[14,15]$. Consequently, the present pilot study was designed to compare serum samples from hemodialysis patients with samples from healthy controls to investigate the effects of end-stage renal disease on serum protein profiles.

Hemodialysis is the primary maintenance treatment modality for end-stage renal failure. There are currently about 400,000 hemodialysis patients in the U.S. Typically these patients receive 4 hour dialysis treatments 3 times per week for life, or until they receive a kidney transplant. Dialysis patients are unusually susceptible to a variety of complications including infections, cardiovascular complications, and defective immune responses. These complications lead to mortality rates of about $15 \%$ per year among dialysis patients [16]. Development of serum diagnostic factors for early detection of 
complications could reduce mortality in this large treatment population if effective treatment strategies are available. Before SELDI-TOF-MS can be applied to this problem, it is important to understand the effects of end-stage renal disease and dialysis treatments on serum protein profiles. Kidney failure can be caused by a variety of underlying complications including diabetes, hypertension, and glomerulonephritis. Each of these etiologies could have a different effect on serum proteins. The dialysis process itself alters the concentrations of low- vs. high-molecular weight proteins in serum depending on the time of sampling. Protein profiles could also be altered by patient responses to the hemodialysis process (e.g. inflammation, cytokine production). Finally, patient-to-patient variation in the presence of other chronic diseases or health complications may be important. While there is a growing literature characterizing specific serum proteins and metabolites in hemodialysis patients [17-20], the focus of this study is to evaluate a broad profile of serum proteins in patients vs. control individuals in order to understand the effects of the complexities described above. A better understanding of these issues would facilitate application of protein profiles to the diagnosis of complications in dialysis patients.

\section{Materials and Methods}

Protocols for this study were reviewed and approved by the LLNL Institutional Review Board and comply with NIH guidelines. Blood samples were obtained with informed consent from 4 unaffected healthy control subjects, and 4 patients that are receiving dialysis treatments three times per week as a consequence of renal failure. Samples from 
dialysis patients were obtained prior to their routine dialysis session. The four dialysis patients (subjects 1-4) consisted of 3 females and 1 male between the ages of 29 and 63 years. Causes of renal failure differed for each of these four patients. End-stage renal disease was secondary to the following causes: diabetes, cyclosporine toxicity, IgA nephropathy, and hypertension. The four control subjects (subjects 5-8) consisted of 2 females and 2 males, with an age range of 32-52 years. Blood from all subjects were collected in $2.5 \mathrm{~mL}$ BD vacutainer SST glass serum tubes (Becton Dickinson, Franklin Lakes, NJ) and spun at $2500 \mathrm{rpm}$ at $4^{\circ} \mathrm{C}$ for $30 \mathrm{~min}$. The separated serum was divided into $0.1 \mathrm{ml}$ aliquots and stored at $-80^{\circ} \mathrm{C}$ until analysis. All samples were coded before sample preparation and MS analysis. SELDI-TOF-MS analysis was performed blindly with no knowledge of the source of the samples. After the experimental work was completed, results were identified as coming from patient or control group samples to compare protein profiles between groups.

Frozen serum samples were prepared for SELDI-TOF-MS as outlined in Figure 1. Each serum sample (subjects 1-8) was thawed and spun at $20000 \mathrm{xg}$ for $10 \mathrm{~min}$ at $4^{\circ} \mathrm{C}$. Thirty $\mu \mathrm{L}$ of $\mathrm{pH} 9.0$ buffer (9 M Urea / 2\% CHAPS / $50 \mathrm{mM}$ Tris- $\mathrm{HCl}$ ) was added to $20 \mu \mathrm{L}$ of each serum sample before mixing with Q Ceramic HyperD® F beads (Ciphergen Biosystems, Fremont, CA) in a filtration plate. Proteins were eluted through the filter by washes with buffers of different $\mathrm{pH}$. Fraction 1 (F1) consisted of flow through and material eluted with $200 \mu \mathrm{L}$ of $\mathrm{pH} 9.0$ buffer. This procedure was repeated for $\mathrm{pH} 7$ buffer (50 mM HEPES), pH 5 buffer (100mM sodium acetate), pH 4 buffer (100mM sodium acetate), pH 3 buffer (50 mM sodium acetate) and an organic solvent buffer (33.3 
$\%$ isopropanol / $16.7 \%$ acetonitrile / $0.1 \%$ trifluoroacetic acid) to give fractions 2 through 6 (F2-F6) respectively. Each fraction was then applied onto four different Ciphergen ProteinChip® Arrays: Weak Cation exchange (WAX2), Strong Anion exchange (SAX2), Immobilized Metal Affinity Capture (IMAC) (Copper II), and Hydrophobic (H50) surfaces. Each array surface was prepared using standard protocols described in the Ciphergen ProteinChip ${ }^{\circledR}$ Applications guide [21]. The energy absorbing molecules (EAMs), $\alpha$-cyano-4-hydroxy cinnamic acid (CHCA) and sinapinic acid (SPA) were deposited on the array spots and allowed to air dry. Different energy absorbing molecules (EAMs) and laser powers were used to optimize detection for proteins differing in molecular weight. CHCA was used as the EAM for proteins with a molecular weight $(\mathrm{MW})<15 \mathrm{kDa}$, while SPA was used primarily for proteins with MW >15 kDa. These fractionations provide a broad coverage of proteins based on chemical class rather than function. A total of 144 Time-of-Flight mass spectra analyzing proteins with mass to charge ratio $(\mathrm{m} / \mathrm{z})$ from $1 \mathrm{kDa}$ to $200 \mathrm{kDa}$ were obtained for each sample (reflecting 72 different conditions in duplicate). For SELDI-TOF-MS, proteins and peptides were detected using a Ciphergen PBS-IIC ProteinChip® Reader, a time-lag focusing, linear, laser desorption/ionization Time-of-Flight mass spectrometer. All spectra were acquired in the positive-ion mode. Each spectrum was an average of 130 laser shots and externally calibrated against a mixture of known peptides or proteins. The spectra were analyzed using the Biomarker Wizard function in ProteinChip® Software v3.1.1.

\section{Results and Discussion}


Overall, the 8 serum samples yielded qualitatively similar protein profiles under the different fractionation and ProteinChip ${ }^{\circledR}$ Array conditions. The data in Figure 2a show a typical example with the major peaks very consistent among all dialysis patients and all controls, with a few minor peaks varying between individuals. It is difficult to quantify the total number of protein features analyzed from each sample because some features appear in multiple conditions, and some minor features are hard to differentiate from noise. Experience with previous studies and literature reports provide an estimate that about 500 to 1000 protein features per sample are detected in a study of this size [15]. A number of clearly defined peaks were observed that consistently distinguish the patient samples (1-4) from the control samples (5-8). The spectra in Figure $2 \mathrm{~b}$ show peaks at 5.8 and $11.7 \mathrm{kDa}$ that have greater intensity in all patients compared with controls, while peaks at 7.7 and $9.3 \mathrm{kDa}$ have reduced intensity in patients compared with controls. A close-up view from another fraction and EAM shows two of these peaks at 9.3 and 11.7 $\mathrm{kDa}$ that consistently distinguish patients from controls (Figure 2c). The majority of peaks, however, show similar amplitudes among all samples.

A listing of protein peaks that differ between patients and controls is shown in Table 1. A total of 15 candidate proteins showed increased intensity in at least 3 out of 4 patients compared with all controls, while 15 candidates showed decreased intensity in at least 3 out of 4 patients. For sixty percent of these candidate protein peaks, intensities for all 4 patients were outside the range for all 4 controls. Thus, most candidate proteins clearly distinguish all patients from all controls in this study. A few samples are listed as outliers in Table 1 as they lacked one or more peaks that were characteristic of their group. In 
addition, data from subject 4 showed two strong peaks at $15.2 \mathrm{kDa}$ and $15.9 \mathrm{kDa}$ that were not present in any of the other 7 samples (Figure 2c), suggesting that another factor besides dialysis may be responsible for these peaks.

The results of this SELDI-TOF-MS study provide an overview of serum protein profile alterations in hemodialysis patients. While it is difficult to quantify the exact frequency of protein alterations, our observation of 30 candidate protein biomarkers that distinguish the two populations is much larger than the 1 to 5 candidate markers reported from similar studies on specific diseases $[9,12,13,22,23]$. Thus, dialysis treatment, or clinical factors present in end-stage renal disease, have a dramatic effect on serum protein profiles. The 4 dialysis patients share most of these 30 protein alterations, and more than half of the marker changes are shared by all patients compared with all controls. This suggests that renal failure in general, or dialysis therapy, both of which are shared by all patients, may have a greater effect on protein profile alterations than the underlying causes of kidney failure that differed among all 4 patients.

A dialysis treatment effect could result from either differential loss of low molecular weight components through the dialysis membrane, or from patient responses to dialysis such as the production of cytokines or inflammatory response proteins. The data in Table 1 show that biomarker proteins vary in molecular weight from $1.9 \mathrm{kDa}$ to $78.8 \mathrm{kDa}$, and that the biomarkers elevated in patients were spread across the full molecular weight range. This suggests that patient physiological responses to dialysis are more important than dialysis membrane fractionation in producing the observed protein profile patterns. 
Finally, the unique protein markers observed in patient 4 suggest other clinical factors may be present in this individual in addition to end-stage kidney disease. One clinical factor that is unique to patient 4 is that this is the only subject with Hepatitis C. Further studies would be required to determine if hepatitis or liver damage has any effect on the protein markers seen in this patient.

In summary, SELDI-TOF-MS provides convenient, rapid method for screening large numbers of serum proteins to characterize protein profile alterations in complex clinical conditions. This pilot study was designed to provide some insights into the effects of endstage renal disease and dialysis treatments on serum protein profiles. The results show a number of factors in hemodialysis that affect the potential use of SELDI-TOF-MS as a diagnostic tool to identify treatment complications and reduce patient mortality. Our results show that while patients differ dramatically from controls, the protein profiles of dialysis patients are similar to each other. Thus, longitudinal studies of patients, using a dialysis pattern as a control may facilitate detection of additional complications. The unique features in patient 4 support the potential of detecting additional clinical conditions. Future studies with longitudinal serum sampling will be required to determine whether treatment related complications could also be detected using this approach.

\section{Acknowledgments}

This work was performed under the auspices of the U.S. Department of Energy by University of California Lawrence Livermore National Laboratory under contract No. W- 
7405-Eng-48, with support from Laboratory Directed Research and Development funding.

\section{References}

1 Tyers M, Mann M: From genomics to proteomics. Nature 2003;422:193-197.

2 Hanash S: Disease Proteomics. Nature 2003;422:226-232.

3 Anderson NL, Anderson NG: The Human Plasma Proteome. Mol Cell Proteomics 2002;1:845-867.

4 Kennedy S: Proteomic profiling from human samples: the body fluid alternative. 2001;120:379-384.

5 Hutchens TW, Yip TT: New desorption strategies for the mass spectrometric analysis of macromolecules. Rapid Commun Mass Spectrom 1993;7:576-580.

6 Issaq HJ, Conrads TP, Prieto AP, Tirumalai R, Veenstra TD: SELDI TOF MS for diagnostic proteomics. Anal Chem 2003; 149A-155A.

7 Paweletz CP, Liotta LA, Petricoin EF: New technologies for biomarker analysis of prostate cancer progression: Laser capture microdissection and tissue proteomics. Urology 2001;57:160-163.

8 Vlahou A, Schellhammer PF, Medrinos S, Patel K, Kondylis FI, Gong L, Nasim S, Wright GL Jr: Development of a novel approach for the detection of transitional cell carcinoma of the baldder in urine. Am J Pathol 2001;158:1491-1501.

9 Zhukov TA, Johanson RA, Cantor AB, Clark RA, Tockman MS: Discovery of distinct protein profiles specific for lung tumors and pre-malignant lung lesions by SELDI mass spectrometry. Lung Cancer 2003;40:267-279. 
10 Wulfkuhle JD, McLean KC, Pawaletz CP, Sgroi DC, Trock BJ, Steeg PS, Petricoin III EF: New approaches to proteomic analysis of breast cancer. Proteomics 2001;1:12051215.

11 Petricoin III EF, Ardekani AM, Hitt BA, Levine PJ, Fusaro VA, Steinberg SM, Mills GB, Simone C, Fishman DA, Kohn EC, Liotta LA: Use of proteomic patterns in serum to identify ovarian cancer. The Lancet 2002;359:572-577.

12 Carrette O, Demalte I, Scherl A, Yalkinoglu O, Corthals G, Burkhard P, Hochstrasser DF, Sanchez JC: A panel of cerebrospinal fluid potential biomarkers for the diagnosis of Alzheimer's disease. Proteomics 2003;3:1486-1494.

13 Clark W, Silverman BC, Zhang Z, Chan DW, Klein AS, Molmenti EP: Characterization of renal allograft rejection by urinary proteomic analysis. Annals of Surgery 2003;237:660-665.

14 Issaq HJ, Veenstra TD, Conrads TP, Felschow D: The SELDI-TOF MS approach to proteomics: Protein profiling and biomarker identification. Biochem Biophys Res Comm 2002;292:587-592.

15 Poon TCW, Yip TT, Chan ATC, Yip c, Yip V, Mok TSK, Lee CCY, Leung TWT, Ho SKW, Johnson PJ: Comprehensive proteomic profiling identifies serum proteomic signatures for detection of hepatocellular carcinoma and its subtypes. Clinical Chemistry 2003;49:752-760.

16 Allon M, Depner TA, Radeva M, Bailey J, Beddhu S, Butterly D, Coyne DW, Gassman JJ, Kaufman AM, Kaysen GA, Lewis JA, Schwab SJ; HEMO Study Group: Impact of dialysis dose and membrane on infection-related hospitalization and death: results of the HEMO Study. J Am Soc Nephrol 2003;14:1863-1870. 
17 Kaysen GA, Durbin JA, Muller HG, Mitch WE, Rosales L, Levin NW; HEMO Group: Impact of albumin synthesis rate and the acute phase response in the dual regulation of fibrinogen levels in hemodialysis patients. Kidney Int. 2003;63:315-322.

18 Caglar K, Peng Y, Pupim LB, Flakoll PJ, Levenhagen D, Hakim RM, Ikizler TA: Inflammatory signals associated with hemodialysis. Kidney Int. 2002;62:1408-1416.

19 Tarakcioglu M, Erbagci AB, Usalan C, Deveci R, Kocabas R: Acute effect of hemodialysis on serum levels of the proinflammatory cytokines: Mediators Inflamm. 2003;12:15-19.

20 Kalantar-Zadeh K, Don BR, Rodriguez RA, Humphreys MH: Serum ferritin is a marker of morbidity and mortality in hemodialysis patients. Am J Kidney Dis. 2001;37:564-572.

21 Ciphergen ProteinChip ${ }^{\circledR}$ Applications guide 107-118. Ciphergen Inc., Fresno, CA, USA.

22 Shiwa M, Nishimura Y, Wakatabe R, Fukawa A, Arikuni H, Ota H, Kato Y, Yamori T: Rapid discovery and identification of a tissue-specific tumor biomarker from 39 human cancer cell lines using the SELDI ProteinChip platform. Biochem Biophys Res Comm 2003;309:18-25.

23 Ye B, Cramer DW, Skates SJ, Gygi SP, Pratomo V, Fu L, Horick NK, Licklider LJ, Schor JO, Berkowitz RS, Mok SC: Haptoglobin-alpha subunit as potential serum biomarker in ovarian cancer: Identification and characterization using proteomic profiling and mass spectrometry. Clinical Cancer Research 2003;9:2904-2911.

\section{Figure Legends}


Fig. 1. Flow chart of serum processing for SELDI-TOF-MS: Elution from a strong ion exchange resin with a $\mathrm{pH}$ gradient to yield six fractions followed by application of each fraction to four different, ProteinChip ${ }^{\circledR}$ Array surfaces.

Fig. 2. Mass spectra of serum samples from the 8 subjects in the study. Subjects 1-4 are dialysis patients, while subjects 5-8 are unaffected healthy controls. Fig. 2a Fraction 4, WCX array surface with CHCA. Note similar peaks with all samples. Fig. 2b Fraction 5, IMAC array surface with CHCA. Note candidate protein markers at 5.8, 7.7, 9.3, 11.7 and $19.7 \mathrm{kDa}$. Fig. 2c. Fraction 2, IMAC array surface with SPA and high laser power. Note candidate protein markers at 9.3 and $11.7 \mathrm{kDa}$, and the unique peaks for subject 4 at 15.5 and $15.9 \mathrm{kDa}$.

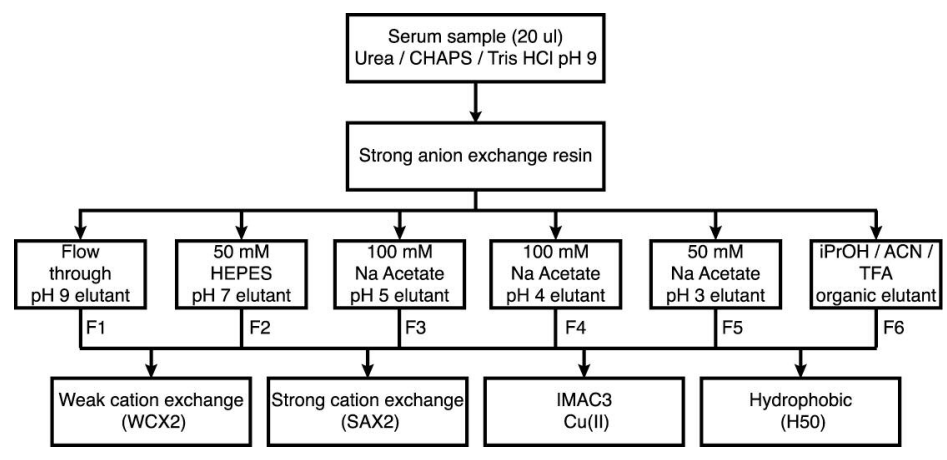

Figure 1 
(a)

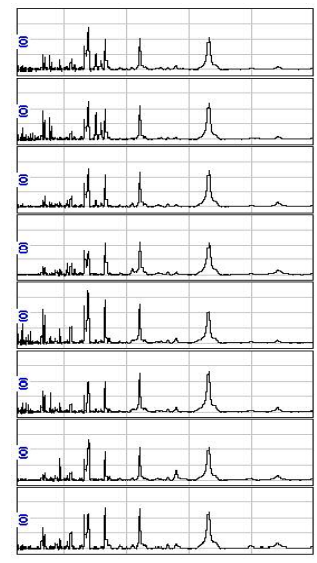

$\begin{array}{llll}10 & 20 & 30 & 40\end{array}$ (b)

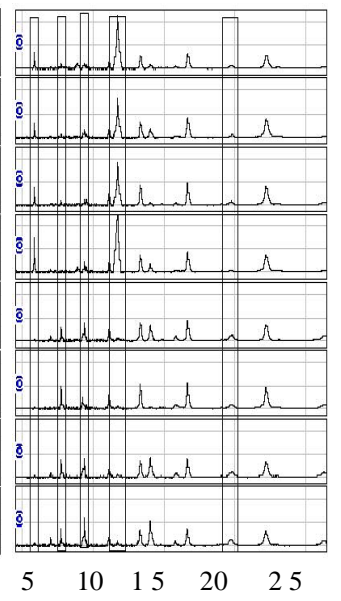

$\mathrm{m} / \mathrm{z}\left(\mathrm{x} 10^{-3}\right)$ (c)

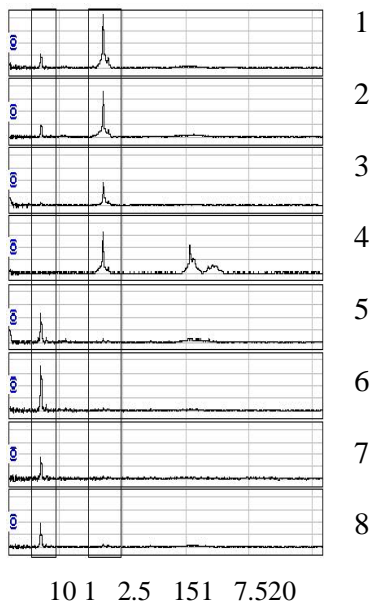

$\begin{array}{lllll}10 & 12.5 & 15 & 17.5 & 20\end{array}$

Figure 2 
Table 1. Candidate protein peaks that distinguish healthy controls from hemodialysis patients.

\begin{tabular}{|c|c|c|c|c|c|}
\hline $\begin{array}{c}\mathrm{MW} \\
(\mathrm{kDa})\end{array}$ & $\begin{array}{l}\text { Peak height } \\
\text { in patients } \\
\text { vs. control }\end{array}$ & $\begin{array}{c}\text { Fraction } \\
\quad \#\end{array}$ & Chip Surface & $\begin{array}{l}\text { EAM / laser } \\
\text { intensity }\end{array}$ & $\begin{array}{c}\text { Outlier } \\
\text { Sample } \\
\#\end{array}$ \\
\hline 78.8 & Lower & 2 & $\mathrm{H} 50$ & SPA high & 6 \\
\hline 51.3 & Higher & 5 & $\mathrm{H} 50$ & SPA high & \\
\hline 50.8 & Higher & 4 & IMAC & SPA high & \\
\hline 45.3 & Lower & 4 & $\mathrm{H} 50$ & SPA high & 6 \\
\hline 43.4 & Higher & 4,6 & $\mathrm{H} 50$ & SPA high & \\
\hline 25.5 & Higher & 5 & IMAC & SPA high & \\
\hline 20.9 & Higher & 5 & WCX & SPA high & \\
\hline 19.7 & Lower & 3 & IMAC & CHCA & \\
\hline 17.3 & Lower & 6 & SAX & SPA low & \\
\hline 15.9 & Higher & 4,6 & $\begin{array}{l}\text { H50, IMAC, } \\
\text { WCX }\end{array}$ & SPA low & 4 \\
\hline 15.2 & Higher & 4,6 & $\begin{array}{l}\text { H50, IMAC, } \\
\text { WCX }\end{array}$ & SPA high, low & 4 \\
\hline 14.7 & Higher & 1 & IMAC & SPA high & \\
\hline 14.1 & Lower & 6 & SAX & SPA low & \\
\hline $\begin{array}{c}13.3 / 13 \\
.4\end{array}$ & Higher & 1 & H50, IMAC & All & \\
\hline 12.8 & Lower & 1 & $\mathrm{H} 50$ & SPA low & \\
\hline 12.6 & Lower & 5 & SAX & SPA high & \\
\hline 12.1 & Lower & 5 & SAX & SPA high & \\
\hline 11.7 & Higher & 2,3 & H50, IMAC & All & \\
\hline 10.3 & Lower & 1 & IMAC & SPA high & 8 \\
\hline 9.3 & Lower & $1,2,3$ & H50, IMAC & All & \\
\hline 8.6 & Higher & 1 & $\mathrm{H} 50$ & $\begin{array}{c}\text { SPA low, } \\
\text { CHCA }\end{array}$ & \\
\hline 8.6 & Lower & 6 & SAX & $\begin{array}{c}\text { SPA low, } \\
\text { CHCA }\end{array}$ & \\
\hline 8.2 & Lower & 5 & $\mathrm{H} 50$ & SPA low & \\
\hline $7.7 / 7.8$ & Lower & $3,4,6$ & IMAC, WCX & $\begin{array}{c}\text { SPA low, } \\
\text { CHCA }\end{array}$ & \\
\hline 7.1 & Higher & 6 & WCX & SPA low & \\
\hline 6.4 & Lower & 5 & $\mathrm{H} 50$ & SPA low & \\
\hline 5.8 & Higher & 3 & IMAC & $\begin{array}{l}\text { SPA low, } \\
\text { CHCA }\end{array}$ & \\
\hline 4.3 & Higher & 1 & $\mathrm{H} 50$ & CHCA & 4 \\
\hline 2.7 & Lower & 1 & WCX & $\mathrm{CHCA}$ & \\
\hline 1.9 & Higher & 1 & WCX & CHCA & \\
\hline
\end{tabular}

Note: Fraction \#, Chip surface, EAM/ laser intensity indicate the experimental conditions used when the candidate peak was observed. Multiple entries (e.g. $9.3 \mathrm{kDa}$ ) indicate that the candidate peak was observed using several experimental conditions. 